\title{
Upregulation of CYP 450s expression of immortalized hepatocyte-like cells derived from mesenchymal stem cells by enzyme inducers
}

\author{
Khanit Sa-ngiamsuntorn' ${ }^{1}$, Adisak Wongkajornsilp ${ }^{1 *}$, Kanda Kasetsinsombat ${ }^{1}$, Sunisa Duangsa-ard ${ }^{1}$, \\ Lalana Nuntakarn ${ }^{4}$, Suparerk Borwornpinyo ${ }^{5}$, Pravit Akarasereenont ${ }^{1}$, Somchai Limsrichamrern ${ }^{2}$ and \\ Suradej Hongeng ${ }^{3 *}$
}

\begin{abstract}
Background: The strenuous procurement of cultured human hepatocytes and their short lives have constrained the cell culture model of cytochrome P450 (CYP450) induction, xenobiotic biotransformation, and hepatotoxicity. The development of continuous non-tumorous cell line steadily containing hepatocyte phenotypes would substitute the primary hepatocytes for these studies.

Results: The hepatocyte-like cells have been developed from hTERT plus Bmi-1-immortalized human mesenchymal stem cells to substitute the primary hepatocytes. The hepatocyte-like cells had polygonal morphology and steadily produced albumin, glycogen, urea and UGT1A1 beyond 6 months while maintaining proliferative capacity. Although these hepatocyte-like cells had low basal expression of CYP450 isotypes, their expressions could be extensively up regulated to 80 folds upon the exposure to enzyme inducers. Their inducibility outperformed the classical HepG2 cells.

Conclusion: The hepatocyte-like cells contained the markers of hepatocytes including CYP450 isotypes. The high inducibility of CYP450 transcripts could serve as a sensitive model for profiling xenobiotic-induced expression of CYP450.
\end{abstract}

Keywords: hepatocyte-like cell, immortalization, CYP450, MSC

\section{Background}

Xenobiotic biotransformation has been classified into 2 phases. The majority of phase I biotransformation was implemented by cytochrome P450 (CYP450) family with 8 major isotypes in human[1]. Each isotype has overlapped spectra of substrates and catalyzes multiple reactions. Activations or suppressions of certain isotypes as a result of precipitant drugs have been associated with several clinically important drug interactions[1]. The phase II biotransformation involved several conjugation reactions (e.g., sulfonation, glucuronidation, acetylation, methylation and glutathione conjugation). These

\footnotetext{
* Correspondence: siawj@mahidol.ac.th; rashe@mahidol.ac.th 1 Department of Pharmacology, Faculty of Medicine Siriraj Hospital, Mahidol University, 2 Prannok Road, Bangkoknoi, Bangkok 10700, Thailand ${ }^{3}$ Department of Pediatrics, Faculty of Medicine Ramathibodi Hospital, Mahidol University, 270 Rama VI Road, Ratchatewi, Bangkok 10400, Thailand Full list of author information is available at the end of the article
}

conjugations attach new functional groups to the xenobiotic that had gone through phase I metabolism[2]. The CYP450 isotypes in rodents are often different in gene regulation and enzymatic activity from those in human and thus cannot reliably predict the toxicity or metabolic profiles of xenobiotics in human[3].

The idealistic cell culture model to simulate in vivo biotransformation of xenobiotics is the use of primary human hepatocytes. However, the acquisition of normal human hepatocytes is cumbersome with ethical as well as biological considerations. The cultured cells are short lived and have to be swiftly prepared from fresh tissues [4] making them unfeasible for most studies. Alternative sources of human cells have been developed to mimic the phenotypes of hepatocytes. A viable source is the mesenchymal stem cells (MSCs) derived from bone marrow[5].

\section{C) Biomed Central}


The very first effort to generate hepatocyte-like cells was taken through the co-culture of MSCs with isolated liver cells[6]. Subsequent efforts employed fetal liverconditioned medium[7], selective cytokines and coating matrix[8]. Alternate cell sources such as adipose tissue [9-11], amniotic fluid[12] and Wharton's jelly[13-15] were employed. The major proposed application of these hepatocyte-like cells is to implement liver regeneration[13,16-19]. The xenogeneic transplants of human hepatocyte-like cells into mice after $\mathrm{CCL}_{4}$-induced liver injury have been attempted with moderate success $[5,20,21]$. Several groups had characterized the phenotypes (i.e., CYP450, morphology, glycogen/urea/albumin production) in contemporary hepatocyte-like cells[22], but none has made the long-term characterization to demonstrate their stability. The long-term stability of the cells is required for the application of xenobiotic testing in new drug development.

The life span of hepatocyte-like cells from these diverse sources after differentiation induction was generally limited. Immortalizing hepatocyte-like cells or their precursors (i.e., MSCs) would be a more feasible solution, resulting in a sustainable and consistent source of hepatocytes. The polycomb group transcription factor Bmi-1[23] that could drive cancer cell proliferation[24] and normal stem cell self-renewal was selected for immortalization. The validity for using these immortalized cells for cell culture metabolic study relies on the maintenance of hepatocyte phenotypes as represented by a panel of specific markers. Hepatocyte-like cells from various MSC sources exhibited different intensities of hepatocyte specific markers [9]. We immortalized the MSC as a precursor for hepatocyte-like cells by using both human telomerase reverse transcriptase gene (hTERT) and Bmi-1 through lentiviral transduction[25], and examined whether the resulting immortalized cells after differentiation induction could maintain hepatocyte phenotypes and metabolic functions.

\section{Results}

The identification of MSCs

Cells isolated from bone marrow aspirate displayed a spindle shape upon reaching confluence (Figure 1A). The hTERT/Bmi-1-transduced MSC (BMI1/hTERTMSC) still maintained fibroblast-like, spindle morphology at $40^{\text {th }}$ passage (Figure $1 \mathrm{~B}$ ) with an exponential growth pattern (Figure 1C). The identity of the studied MSCs was confirmed by the presence of mesenchymal stem cell markers (CD90 and CD105, Figure 1D). MSCs that had gone through immortalization still contained similar levels of CD90 and CD105 (Figure 1E), but was virtually devoid of hematopoietic markers (CD34, CD45, Figure 1F) as determined by a flow cytometer.

\section{Proliferative activity of transformed MSCs}

The growth rate of MSCs was slow at the first passage, picked up and steadily increased in subsequent $\left(2^{\text {nd }}-7^{\text {th }}\right)$ passages. In later $\left(8^{\text {th }}-10^{\text {th }}\right)$ passages, growth rate was again slowed down to a complete stop (Figure 1C). To bypass the replication senescence, we transformed MSCs with either hTERT plus Bmi-1 (BMI/hTERTMSC) or hTERT alone (hTERT-MSC) from 5 independent donors. After 60 days or 20-25 population doubling level (PDL), the proliferation rate of untreated MSCs decreased to a final stop. The cellular morphology switched to epithelial-like, indicating the reduction of stem cell properties. In contrast, BMI/hTERT-MSC grew steadily for more than 8 months (75-80 PDL) and exhibited unaltered morphology (Figure 1C). In contrast, hTERT-MSCs, similar to untreated MSCs, could not bypass replication senescence. BMI/hTERT-MSC cells have been maintained for over a year, confirming their immortalization. To ensure that both Bmi-1 and hTERT were expressed in these transformed MSCs, specific primers were designed to separately quantify endogenous and exogenous expression of both Bmi-1 and hTERT using quantitative RT-PCR. The endogenous expressions of hTERT and hBmi-1 in untreated MSCs at the $4^{\text {th }}$ passage were lower than those in transformed MSCs at the same passage. The ectopic expressions of both hTERT and Bmi-1 were detected at a steadily high level for over a year (120 PDL, Figure 1G). The morphology was also stable throughout the study. Our success rate for immortalization of MSC was 4 clones out of 10 clones from each donor.

\section{The differentiation of MSCs to hepatocyte-like cells}

After finishing hepatic induction, the hepatocyte-like cells carried the expansion of several basic hepatocyte genes (Figure $1 \mathrm{H}$ ) with a corresponding polygonal morphology (Figure 2A). Immortalized hepatocyte-like cells at the first passage were loosely attached to adjacent cells (Figure 2B). Up to $70-80 \%$ of the hepatocyte-like cells deposited glycogen, especially in densely populated area (PAS assay at passage 4, Figure 2C). After switching to $10 \% \mathrm{FBS}, \mathrm{DMEM} / \mathrm{F} 12$ the intercellular attachment was denser with blurring of cell boundary (Figure 2D). At confluence, duct-like structure was observed (Figure $2 \mathrm{E})$. The cells could maintain cell division beyond 3 months (Figure 2F) with sustainable hepatocyte function suitable for drug screening.

\section{Expression levels of hepatocyte-specific markers}

Up to $88 \%$ of hepatocyte-like cells (Figure 3A) and immortalized hepatocyte-like cells (Figure 3B), as opposed to $5 \%$ of MSCs, contained intracellular albumin. Almost $95 \%$ of HepG2 cells contained albumin (Figure $3 C$ ). In subsequent passages, hepatocyte-like 


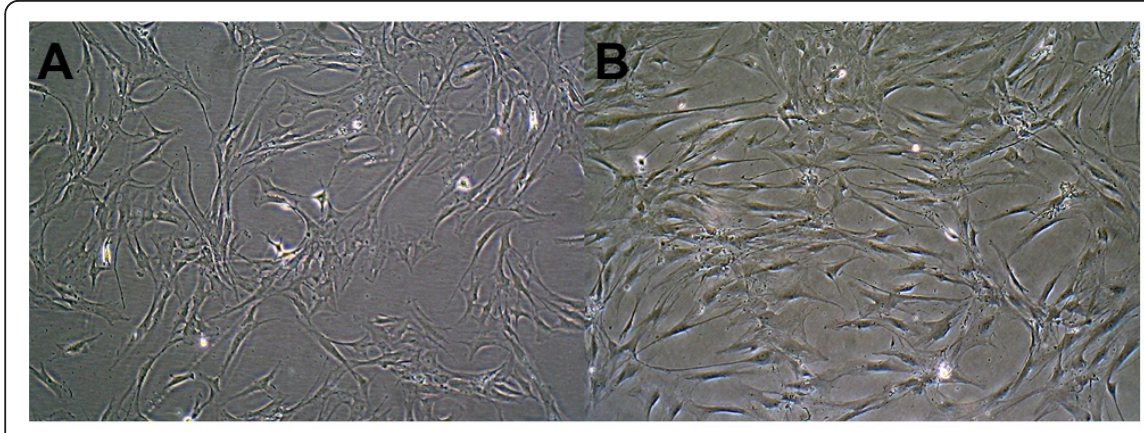

D

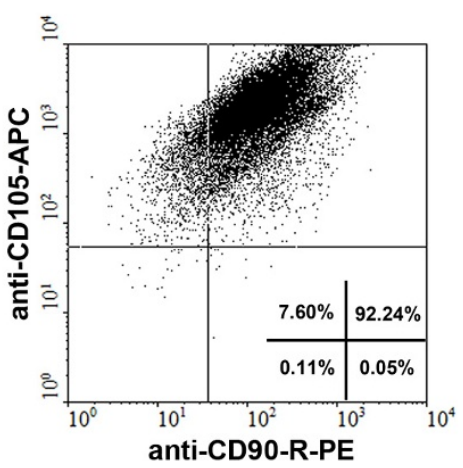

E

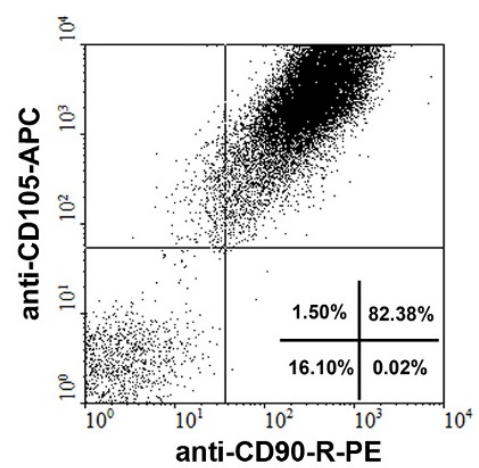

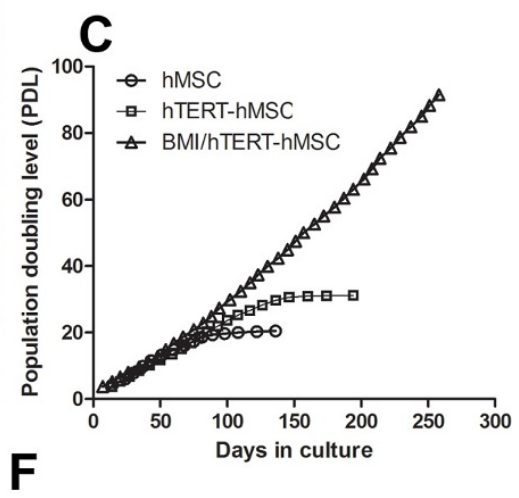

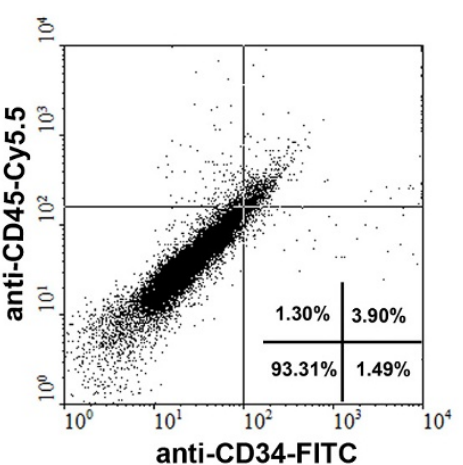

G

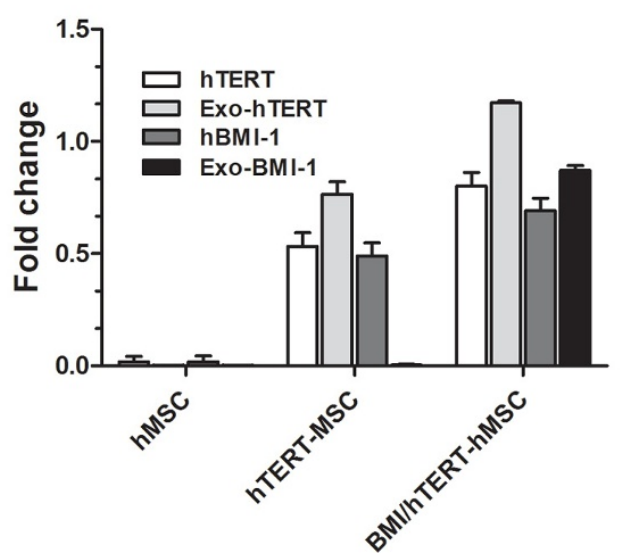

H

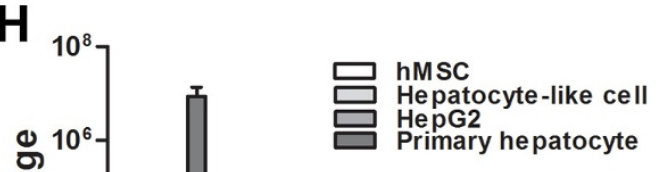

Figure 1 Characterization of immortalized MSC. MSCs and Bmi-1/hTERT-immortalized MSCs were visualized (A) after the $2^{\text {nd }}$ passage. The attached cells appeared fibroblast-like, spindle morphology (B) at the $40^{\text {th }}$ passage (12 months after isolation). The MSCs (hMSC) and the TERT-transduced MSCs (hTERT-MSC), or the double TERT/Bmi-1 transduced MSCs (BMI/hTERT-MSC) were studied for cumulative population doubling level (PDL) (C). Flow cytometry analysis confirmed the presence of CD90/CD105 in primary MSCs after isolation (D) and in BMI/hTERT-MSCs (E). All cells were depleted of CD35/CD45 hematopoietic stem cell markers (F). The endogenous and exogenous expression of Bmi-1, TERT in all cell types were studied using quantitative real-time PCR (G). The expression of hepatocyte-selective genes (i.e., albumin (ALB), $\alpha$-fetoprotein (AFP), cytokeratin18 (CK18), glucose-6phosphate dehydrogenase (G6PD), hepatocyte nuclear factor (HNF-4 $\alpha$ ), and tyrosine aminotransferase (TAT)) of BMI/hTERT-MSC after hepatic differentiation was presented as fold change over the untreated MSCs in comparison with HepG2 and the primary hepatocyte (H).

cells maintained at least $70 \%$ of albumin-containing cells (Figure 3D). The functional activity of hepatocyte-like cells at different passages was investigated using urea assay (Figure 3E). The conditioned medium of hepatocyte-like cells contained far higher level of urea than that of MSCs, but was comparable to that of HepG2. Using mRNA levels inherent to MSCs as a reference, the relative expression levels of the 


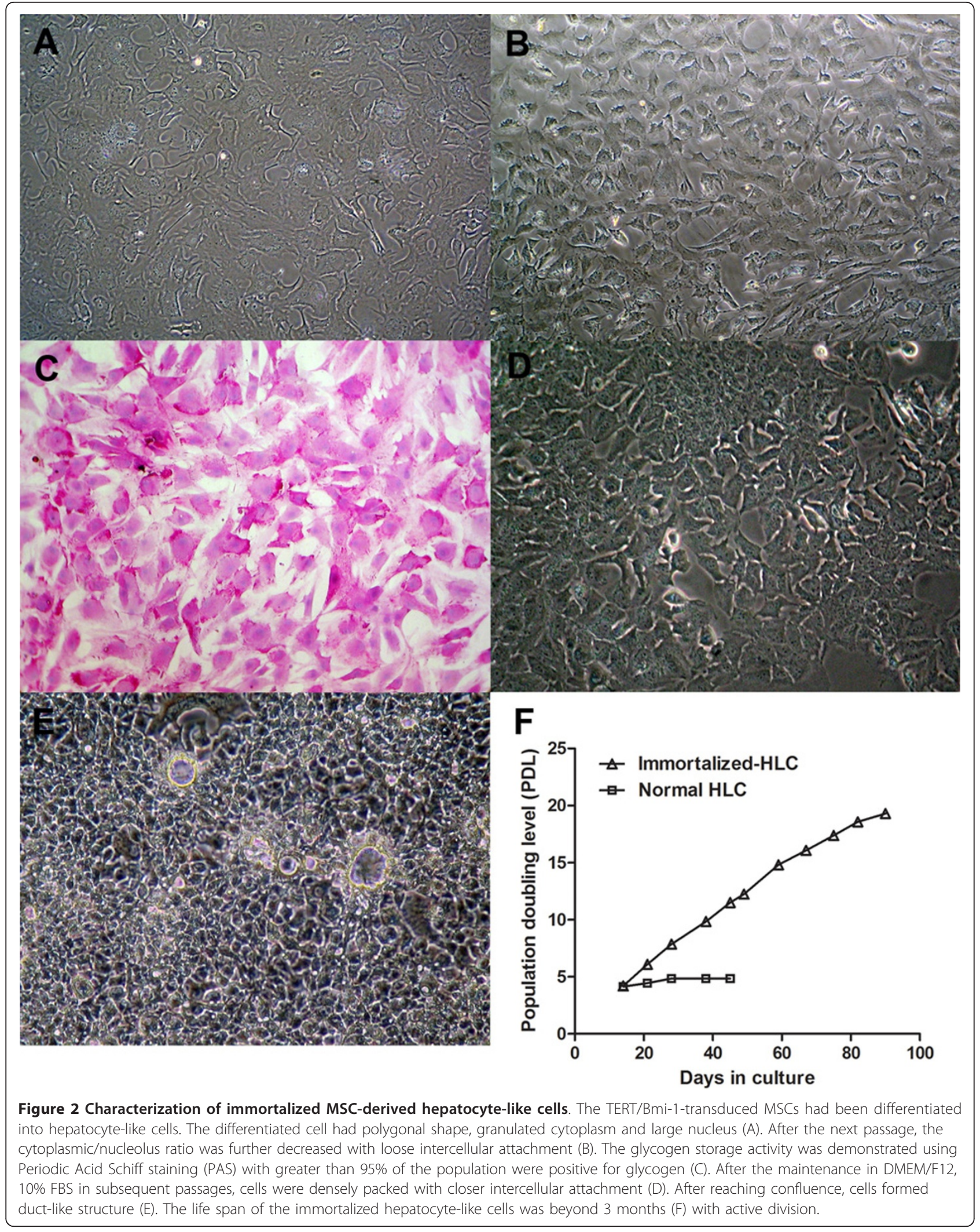




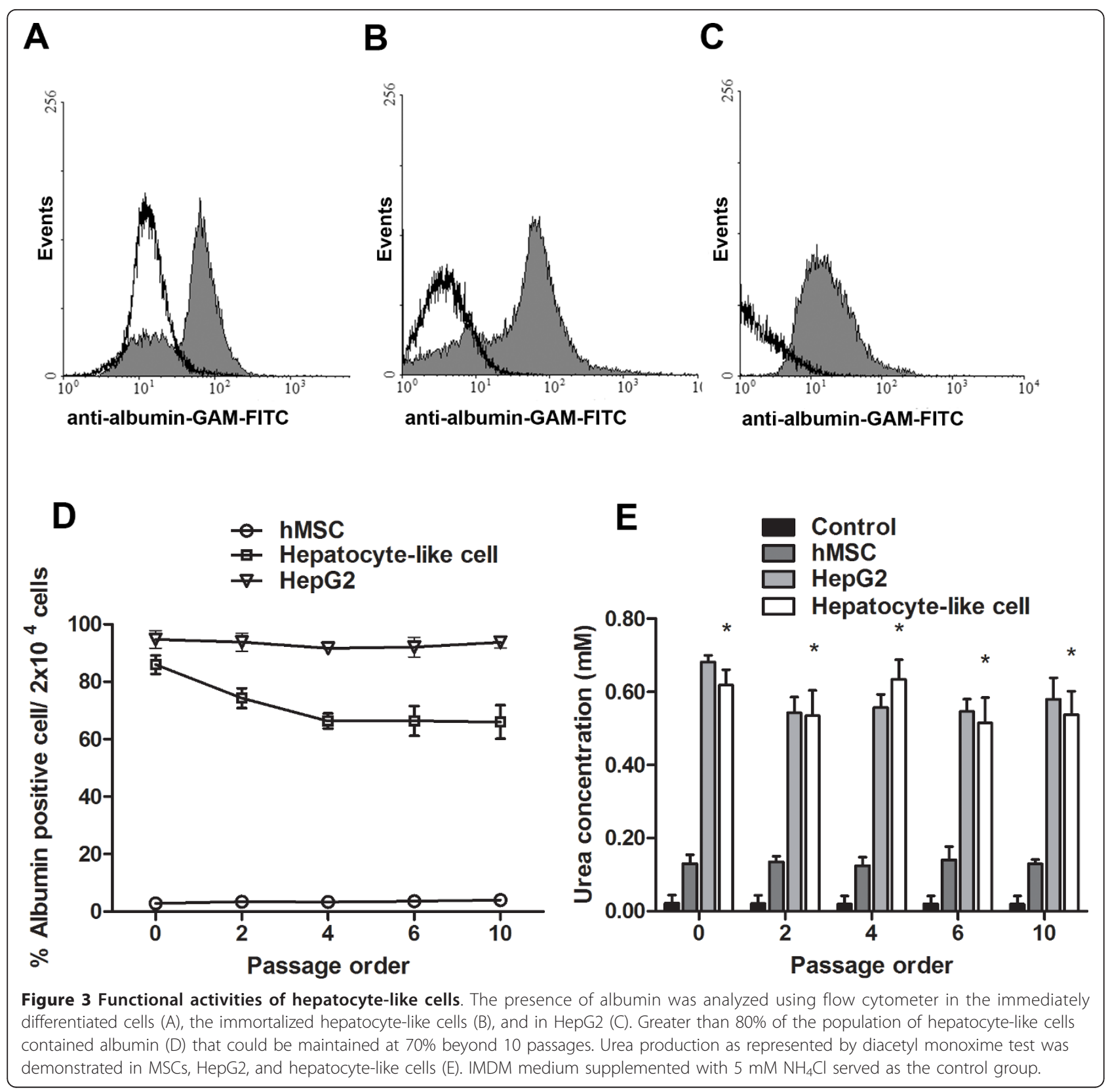

corresponding genes in the hepatocyte-like cells, HepG2 cells and the primary human hepatocytes were determined using quantitative real-time PCR. The basal expression patterns for hepatocyte-specific genes at passage 5-9 (e.g., ALB, AFP, CK18, G6PD, HNF- $4 \alpha$ and TAT) were varied, depending on the stage of hepatocyte maturation. The AFP expression that is usually presented in hepatic progenitors was detected at higher level than those of the primary human hepatocytes and HepG2 cells (Figure 1H). The observation of cytokeratin18 expression confirmed the differentiation of MSCs into endodermal tissue. Three major hepatocyte genes were up-regulated in hepatocyte-like cells, namely glucose-6-phosphate dehydrogenase (glucose metabolism), HNF- $4 \alpha$ (liver development and maturation) and tyrosine aminotransferase (amino acid metabolism). The observation of all hepatocyte specific genes confirmed that the transformed MSCs could actually differentiate into functional hepatocyte-like cells.

The basal expression of phase I and phase II enzymes in hepatocyte-like cell

After maturation induction, hepatocyte-like cell culture was continued in IMDM with 1\% FBS, 2\% DMSO for 2 


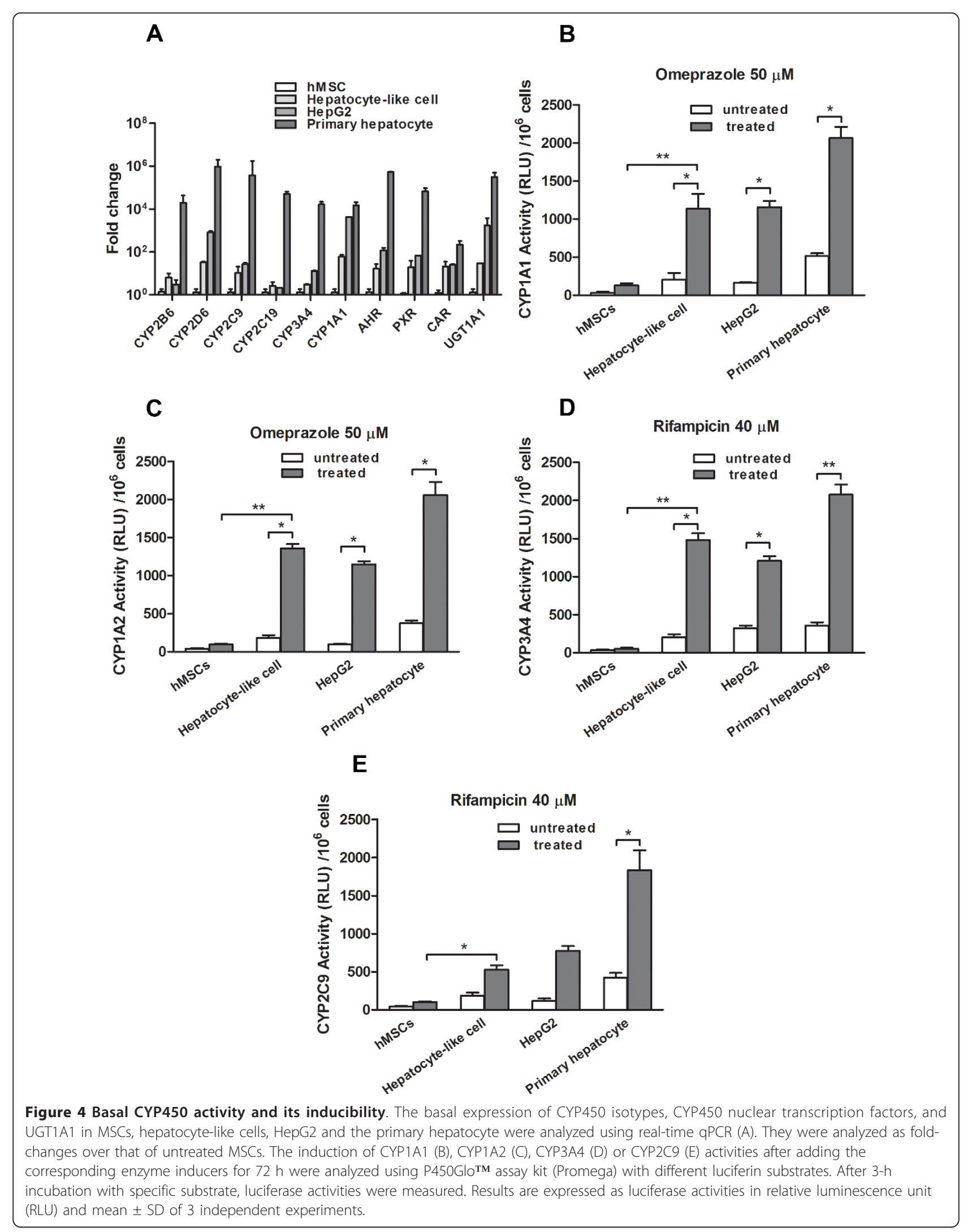


weeks at confluence [26]. Cells were harvested and determined for phase I and phase II enzyme expressions (Figure 4A). Specific transcription factors such as AHR, PXR and CAR in hepatocyte-like cells were increased by about 10 times those of MSCs. These genes are involved in the transcription of CYP450 isotypes [27,28]. Genes that were highly expressed in hepatocyte-like cells included one phase II enzyme UGT1A1 and 6 CYP450 isotypes (CYP2B6, CYP2D6, CYP2C9, CYP2C19, CYP3A4, and CYP1A1). In particular, the expression level of CYP2B6 in hepatocyte-like cells was even higher than that of HepG2 while other isotypes achieved comparable expression levels to those of HepG2. However, all CYP450 isotype expressions in hepatocyte-like cells were only $10-20 \%$ that of normal hepatocytes. The authenticity of the real-time RT-PCR products of hepatocyte markers and CYP450 were confirmed through the analysis for melting curve using Sequence Detection Software version 2.01 (Applied Biosystems, CA).

\section{Enhancing phase I enzyme expression using prototypic inducers}

The expressions of CYP1A1, CYP2B6, CYP2D6 and CYP2C8 in hepatocyte-like cells were significantly increased to $13,30,3,12$ folds respectively after the induction with dexamethasone or rifampicin (Table 1). CYP3A4 and CYP2C19 expressions were extensively up regulated by 84 and 20 folds, respectively in hepatocytelike cells. In HepG2, the expressions of CYP2B6, CYP2C8 and CYP3A4 were increased to 25, 9, 39 folds using rifampicin. In the primary hepatocyte, the expression of CYP1A1, CYP1A2, CYP2B6 were raised to 19, 13,41 folds that were comparable to those of the hepatocyte-like cells. The induction of CYP3A4 expression in the hepatocyte-like cells (84 folds) outpaced that of the primary hepatocyte (72 folds). The expressions of most CYP450 isotypes in undifferentiated MSCs were induced by merely $2-4$ folds.

\section{Substantial induction of CYP1A1, CYP1A2, CYP2C9 and CYP3A4 isotype activities in hepatocyte-like cells}

Using luminescent CYP450-specific substrates, we determined CYP1A1, CYP1A2, CYP2C9 and CYP3A4 isotype activities after the induction with either rifampicin or omeprazole in HepG2, MSC and hepatocytelike cell. We observed end-point catalytic activity after incubating substrates to the cells using a luminometer. In hepatocyte-like cell, the activity of CYP1A1, CYP1A2 and CYP3A4 was increased to approximately 6-7 folds that of the untreated cell (Figure 4B, C, D). A mild increase in CYP2C9 activity (2 folds) was observed (Figure 4E). The activity of CYP1A2 and CYP3A4 in hepatocyte-like cells was already higher than those in HepG2. The primary hepatocyte provided the highest activities in all CYP450 isotypes. A significant increase in rifampicin-induced CYP3A4 activity was confirmed by the accumulation of CYP450 in hepatocyte-like cell as demonstrated by immunofluorescent staining (Figure 5A). The staining for AFP and hepatocyte nuclear factor $4 \alpha$ confirmed the identity of the hepatocyte-like cell. The corresponding staining to the primary hepatocyte served as the positive controls (Figure 5B). No significant induction was detected in untreated MSCs, but untreated HepG2 and untreated hepatocyte-like cell had low basal level of CYP1A1, CYP1A2, CYP2C9 and CYP3A4 activities.

\section{Discussion}

The hepatocyte-like cells have been developed to replace the primary hepatocytes for the studies of xenobioticinduced CYP450 isotype expression, hepatotoxicity, and xenobiotic biotransformation. Taken together, the cell morphology, cell-selective markers (i.e., gene expression profiles, flow cytometry) as well as certain specific phenotypes (urea synthesis, glycogen deposit, and CYP450 expression profiles) indicated that the putative hepatocyte-like cells were correctly driven toward hepatocyte differentiation. To our knowledge, there has not been any attempt to bring hepatocyte-like cells derived from MSC as a stable model for the study of CYP450 isotypes or new drug development. Only certain isotypes (CYP1A1, CYP1A2, CYP2B6, CYP7A1 and CYP2E1) have been studied immediately after differentiation $[18,29,30]$. The expression of various transcription factors that regulate CYP450 isotypes[31] including hepatocyte nuclear factor (HNF-4 $\alpha$ ) [32] during hepatogenic differentiation has been reported. PXR, AHR and CAR are considered to be the most important regulators of xenobiotic-induced regulation of many CYP450 isotypes [28]. We observed increasing expression of PXR, CAR and HNF- $4 \alpha$ in correlation with the degree of hepatocyte-like cell maturation.

Several investigators had developed hepatocyte-like cells from different stem cell sources and various differentiation protocols[33]. The MSC sources were bone marrow, adipose tissue and Wharton's jelly[10,29,34,35]. The differentiation phenotypes were generally lost after a few days in all studies including one employing embryonic stem cells as precursors[36]. The senescence of the precursor MSCs led to decreasing both proliferation and plasticity [37-39]. Our MSCs also reached senescence after 20-24 population doublings, similar to others [40-42]. The generation of hepatocyte-like cells from MSCs has been plagued by the lack of stable supply of the precursor MSCs and their differentiation capacity. These obstacles would be obviated if immortalized hepatocyte-like cells with intact phenotypes could be generated. 
Table 1 Fold changes of CYP450 isotypes' expression in three cell types after $72 \mathrm{~h}$ of induction with prototypic CYP450 inducers (omeprazole, dexamethasone, rifampicin, artemisinine and ethanol) over the untreated control

\begin{tabular}{|c|c|c|c|c|c|}
\hline \multirow[t]{2}{*}{ P450 isotypes/enzyme inducers } & \multirow[t]{2}{*}{ concentration $(\mu \mathrm{M})$} & \multicolumn{4}{|c|}{ mRNA fold change (mean \pm SD) } \\
\hline & & HepG2 & P-hepatocyte & hMSC & Hep-like cell \\
\hline \multicolumn{6}{|l|}{ CYP1A1 } \\
\hline omeprazole & 50 & $4.05 \pm 0.38^{*}$ & $11.13 \pm 0.34^{*}$ & $2.09 \pm 0.30$ & $2.13 \pm 0.15$ \\
\hline dexamethasone & 25 & $1.11 \pm 0.13$ & $19.68 \pm 0.46^{*}$ & $3.10 \pm 0.33^{*}$ & $12.86 \pm 0.39^{*}$ \\
\hline \multicolumn{6}{|l|}{ CYP1A2 } \\
\hline omeprazole & 50 & $3.33 \pm 0.14^{*}$ & $6.44 \pm 0.80$ & $1.67 \pm 0.12$ & $2.37 \pm 0.13$ \\
\hline dexamethasone & 25 & $1.17 \pm 0.02$ & $13.62 \pm 2.84^{*}$ & $3.82 \pm 0.96^{*}$ & $5.63 \pm 0.65^{*}$ \\
\hline \multicolumn{6}{|l|}{ CYP2B6 } \\
\hline rifampicin & 40 & $25.82 \pm 1.30^{*}$ & $35.16 \pm 2.76^{* *}$ & $1.46 \pm 0.10$ & $30.70 \pm 5.36^{* *}$ \\
\hline dexamethasone & 25 & $2.58 \pm 0.72$ & $41.49 \pm 4.58^{* *}$ & $3.98 \pm 0.71^{*}$ & $24.25 \pm 2.30^{*}$ \\
\hline \multicolumn{6}{|l|}{ CYP2D6 } \\
\hline dexamethasone & 25 & $1.26 \pm 0.10$ & $5.70 \pm 1.29$ & $2.68 \pm 0.43$ & $2.90 \pm 0.73$ \\
\hline \multicolumn{6}{|l|}{ CYP2C9 } \\
\hline rifampicin & 40 & $1.42 \pm 0.25$ & $15.25 \pm 2.51^{*}$ & $2.03 \pm 0.22$ & $7.78 \pm 1.82^{*}$ \\
\hline \multicolumn{6}{|l|}{ CYP2C19 } \\
\hline rifampicin & 40 & $1.87 \pm 0.11$ & $29.05 \pm 2.02^{* *}$ & $2.42 \pm 0.61$ & $19.01 \pm 2.51^{*}$ \\
\hline \multicolumn{6}{|l|}{ CYP2C8 } \\
\hline rifampicin & 40 & $9.07 \pm 1.03^{*}$ & $24.40 \pm 2.48^{*}$ & $3.03 \pm 0.62^{*}$ & $12.28 \pm 0.81^{*}$ \\
\hline \multicolumn{6}{|l|}{ CYP3A4 } \\
\hline rifampicin & 40 & $39.43 \pm 5.53^{* *}$ & $69.50 \pm 6.84^{* *}$ & $3.64 \pm 1.82^{*}$ & $43.29 \pm 3.27^{* *}$ \\
\hline dexamethasone & 25 & $23.18 \pm 7.25^{* *}$ & $72.27 \pm 5.64^{* *}$ & $2.87 \pm 0.96$ & $84.10 \pm 9.25^{* *}$ \\
\hline artemisinine & 50 & $48.18 \pm 6.80^{* *}$ & $59.28 \pm 8.41^{* *}$ & $0.89 \pm 0.07$ & $53.54 \pm 1.37^{* *}$ \\
\hline \multicolumn{6}{|l|}{ CYP2E1 } \\
\hline ethanol & 88 & $4.59 \pm 0.53^{*}$ & $24.23 \pm 0.41^{*}$ & $1.46 \pm 0.19$ & $10.74 \pm 2.10^{*}$ \\
\hline
\end{tabular}

hMSC, HepG2, primary hepatocyte and hepatocyte-like cell were induced with prototypic inducer drugs. The CYP450 mRNA level was detected by Real-time PCR. The experiment was performed in triplicate for all compounds. Data was normalized by untreated (non-treated controls) and was analyzed by Non parametric One-tailed Student $t$ test (Mann-Whitney test) ${ }^{*} p<0.05$, ${ }^{* *} p<0.01$.

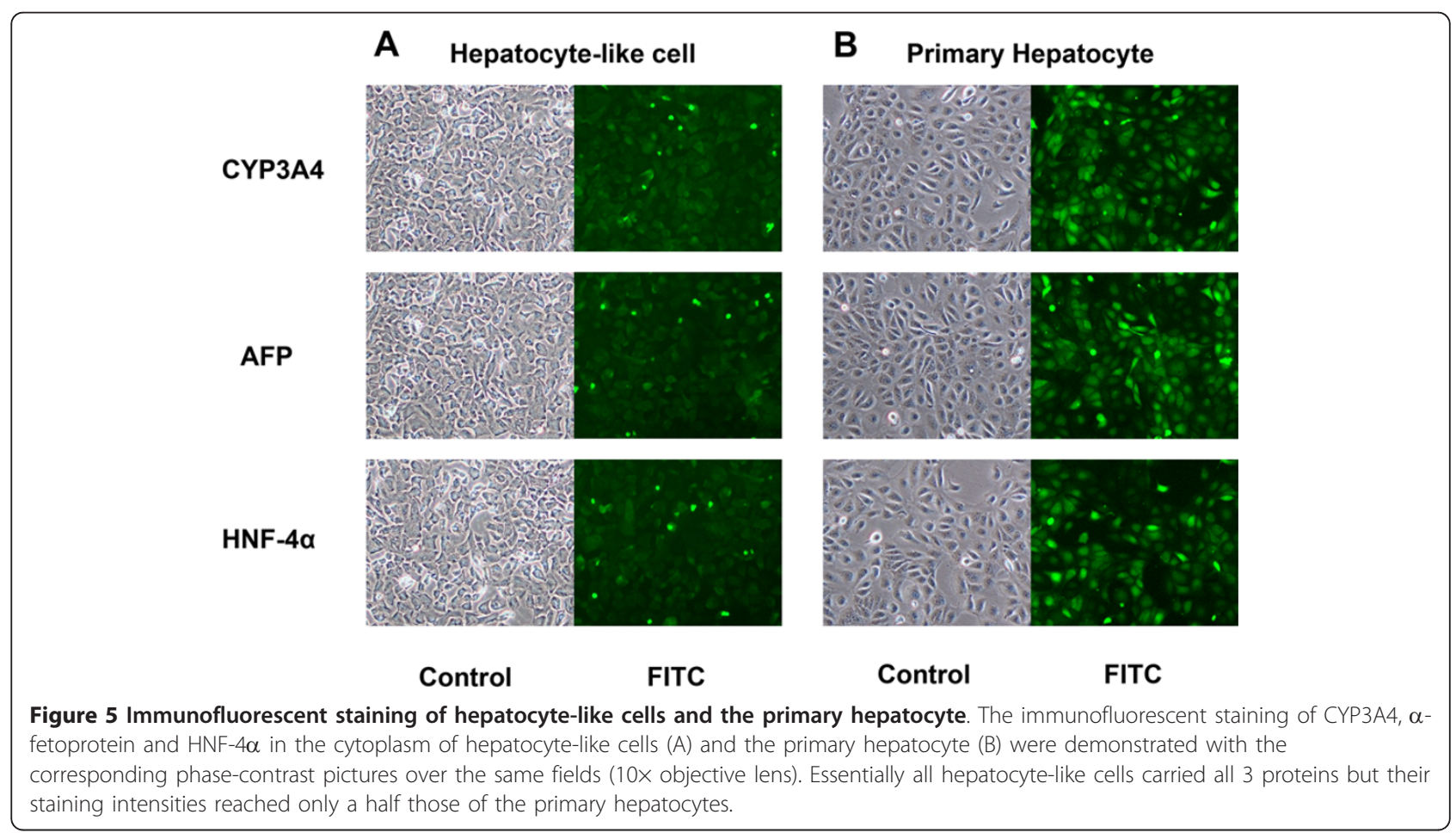


A classical gene employed for immortalization is the telomerase reverse transcriptase (hTERT) that prevents replicative senescence associated with decreasing telomere length resulting from repeated cell division $[43,44]$. Lesser known immortalization genes are SV-40 large $\mathrm{T}$ antigen ( $\mathrm{T}-\mathrm{Ag}$ ) and $\mathrm{Bmi}-1$ [25]. Bmi-1 inhibit senescence and extended the life span of normal human cell by suppressing $\mathrm{p} 16^{\mathrm{INK} 4 \mathrm{~A}}$ that allows cell entry into division[45]. Moreover, the overexpression of Bmi-1 could inhibit TGF- $\beta$ signaling[46] that would otherwise induce hepatocyte cell death[47].

MSCs lost their originally high telomerase activity [48] after being seeded as primary cultured cells [49] and eventually lost their stem cell property [50]. We had expected that the addition of a constitutively expressing construct of hTERT (pLOX-TERT-iresTK) to MSCs would solve the senescence $[51,52]$, but a slight postponement of senescence was observed. Only after Bmi-1 (pLOX-CWBmi1)[53] had been co-introduced were the senescence phenotypes extensively delayed. The transduced cells had increasing spindle morphology with at least $80 \%$ of the whole population contained both CD90 and CD105. These cells could be maintained for over 1 year while still maintaining their growth in exponential phase. The given constructs have an advantage of the inclusion of $\operatorname{loxP}$ site that allows the removal from the genomic insertion site.

It is even more exciting when the precursor cells of the hepatocyte-like cells were already immortalized. We modified the hepatogenic differentiation protocol from previous reports [54] by extending the last step of maturation from 2 weeks to 4 weeks in culture medium supplemented with $2 \%$ DMSO. Normally, we cannot achieve a complete hepatocyte differentiation. However, after using limiting dilution technique, a stable clone of functional hepatocyte-like cell was established. Our clone of differentiated immortalized cells could propagate in standard culture condition for greater than 6 months with sustainable hepatocyte specific makers and functions.

The confirmed hepatocyte phenotypes that included the expression of albumin, $\alpha$-fetoprotein cytokeratin 18 , HNF- $4 \alpha$, and tyrosine aminotransferase were up-regulated for 10 - 100 folds that of the undifferentiated MSCs. However, the overall basal gene expressions were $10-40 \%$ those of the primary hepatocyte. The flow cytometry analysis indicated that at least $80 \%$ of the hepatocyte-like cells, in comparison with $90 \%$ of HepG2, produced albumin. Likewise, the urea production of our cells was comparable to that of HepG2. Greater proportion of our hepatocyte-like cells (> 95\%) carried glycogen than did others $[9,30,55,56]$. The expression of transcription factors for CYP450 (i.e., CAR, AHR, PXR) as well as that of the phase II enzyme (i.e., UGT1A1) was observed. The 10 - 50-fold induction of the expression of 8 major CYP450 isotypes (CYP1A1 CYP1A2, CYP2B6, CYP2D6, CYP2C9, CYP2C19, CYP2C8, CYP3A4 and CYP2E1) in response to known enzyme inducers (rifampicin, dexamethasone, omeprazole, phenobarbital and artesunate) was confirmed, although their basal levels were less than those of the primary hepatocyte by 100-1000 folds. Unexpectedly, HepG2 achieved much weaker induction of CYP1A1, CYP2D6, CYP2C9 and CYP2C19 in response to rifampicin, dexamethasone and omeprazole than did hepatocyte-like cells. The immunofluorescent study of CYP3A4 in hepatocyte-like cells after induction indicated that the upregulation of protein level was consistent with the induction of mRNA expression.

Although CYP450 isotypes are presented in most cell types, not all cell types are suitably employed to study the CYP450's response to xenobiotics. To elucidate the suitability of the hepatocyte-like cells for the study of CYP450 isotypes, we have extensively investigated the expressions of all major isotypes plus the enzymatic activity of selected isotypes in response to enzyme inducers. We have demonstrated that the un-modified MSCs contained low basal levels of CYP450 isotypes and elicited only 2 - 5-fold induction to prototypic CYP450 isotype inducers (Table 1). Therefore, the use of MSCs is not considered a viable alternative for CYP450 study. We observed extensively high expressions of most CYP450 isotypes in response to inducers in hepatocytelike cells than those in MSCs or HepG2, although the basal levels of certain CYP450 isotypes were lower than those of primary hepatocytes or HepG2. Changing the precursors of hepatocyte-like cells from MSCs to embryonic stem cells or induced pleuripotential stem cells could not bring up the basal levels of all isotypes [57]. An exception was found in CYP2B6, where the hepatocyte-like cells had comparable expansion to that of the HepG2. The low basal levels of these CYP450 isotypes in hepatocyte-like cells might be attributed to their completely lack of exposure to xenobiotics as opposed to the primary hepatocytes or HepG2. Based on the expansion of CYP450 isotypes' expression in response to inducers, hepatocyte-like cells are considered a more sensitive and informative model.

\section{Conclusion}

The continuous hepatocyte-like cell lines have been generated from hTERT plus Bmi-1-immortalized human MSCs. These continuous cell lines contained hepatocyte markers (albumin, AFP, TAT, HNF-4 $\alpha$, G6PD) including all major CYP450 isotypes (CYP1A1, CYP1A2, CYP2C8, CYP2B6, CYP2D6, CYP2C9, CYP2C19, CYP3A4 and CYP2E1). The basal mRNA expression of CYP450 isotypes was low, but readily up-regulated up to 
80 folds upon the exposure to enzyme inducers. The high inducibility of CYP450 transcripts would serve as a sensitive model for profiling xenobiotic-induced expression of CYP450.

\section{Methods}

The characterization of human mesenchymal stem cells Human mesenchymal cells (MSCs) were prepared from aspirated bone marrow of consenting normal volunteers $(\mathrm{n}=5)$. This study received an approval from the Ethics Committee on Research Involving Human Subjects at Ramathibodi Hospital, Mahidol University. Written inform consent was obtained from all participants involved in this study. Bone marrow mononuclear cells were separated by IsoPrep (Robbins Scientific, Canada) density gradient centrifugation [58] and seeded at a density of $2 \times 10^{6}$ cells $/ \mathrm{mL}$ in Minimum Essential Medium $(\mathrm{MEM}) \propto$ Media (Gibco Invitrogen, NY), 10\% fetal bovine serum (FBS, Biochrom AG, Germany), 100 units/ $\mathrm{mL}$ penicillin, $100 \mu \mathrm{g} / \mathrm{mL}$ streptomycin at $37^{\circ} \mathrm{C}$ in $5 \%$ $\mathrm{CO}_{2}$. The identification of MSCs was confirmed using FACS analysis. Isolated cells were detached by trypsin, stained for MSC markers (CD105 and CD90) or hematopoietic stem cell markers (CD34, CD45), and analyzed by flow cytometry (FACSCalibur, Becton Dickinson).

\section{Lentivirus production and transduction of target cells}

Viral particles were produced using the transient transfection protocol[25]. HEK 293T cells (Clontech, CA) at a density of $2.8 \times 10^{6}$ cells $/ 10-\mathrm{cm}$ tissue culture dish were co-transfected with psPAX2 packaging vector, pMD2.G vesicular stomatitis virus $G$ envelope, and the plasmid encoding either hTERT (pLOX-TERT-iresTK, Addgene plasmid 12245) or Bmi-1 (pLOX-CWBmi1, Addgene plasmid 12240)[53] using calcium phosphate precipitation. The supernatant was harvested and filtered through a $0.45 \mu \mathrm{m}$ syringe filter. Viral stocks were stored at $-70^{\circ} \mathrm{C}$. For immortalization, both hTERT and Bmi-1 lentiviruses were diluted in MEM $\alpha$ medium, $10 \% \mathrm{FBS}, 6 \mu \mathrm{g} / \mathrm{mL}$ polybrene at a multiplicity of infection (MOI) of 2, and directly added to the MSCs on sixwell plates $\left(10^{4}\right.$ cells/well). The MSCs were incubated at $5 \% \mathrm{CO}_{2}, 37^{\circ} \mathrm{C}$ for $14 \mathrm{~h}$. After the incubation, medium containing viral particles was removed and replaced with fresh medium.

\section{Cloning of immortalized human mesenchymal stem cell} Three days after the infection, MSCs from 5 donors were trypsinized and counted using a hemacytometer. Single cell suspension was prepared by limiting dilution and transferred onto 24-well culture plate to establish clones from single cells. Each colony was monitored every 2-3 d until confluence. The cells were then trypsinized and seeded on T-25 tissue culture flask. To establish stable MSC lines, 10 clones per donor were selected based on the fastest cellular proliferation and confirmed for the expression of both hTERT and Bmi-1. Total RNA of MSC was isolated from pooled cells of passages 3-5, converted into cDNA and quantitated using real-time PCR. hTERT and Bmi-1 double positive cells were studied for population doubling level (PDL). The population doubling level was determined using log $\mathrm{N} / \log 2$, where $\mathrm{N}$ is the number of the cells harvested at confluence divided by the number of the initially seeded cells [25].

\section{The induction of MSC hepatogenesis}

The MSCs at passages 3-5 or BMI/hTERT-MSCs at a density of $1 \times 10^{4}$ cells $/ \mathrm{cm}^{2}$ from the fastest dividing clone $(\mathrm{n}=3)$ were taken for differentiation. The MSCs were induced into hepatocyte-like cells using a modified three-step protocol[9]. They were maintained on collagen type IV coated container. The cells were maintained for $2 \mathrm{~d}$ in serum-free IMDM (Gibco Invitrogen, $\mathrm{NY}$ ), $20 \mathrm{ng} / \mathrm{mL}$ epidermal growth factor (EGF, Chemicon, CA), $10 \mathrm{ng} / \mathrm{mL}$ basic fibroblast growth factor (bFGF, Chemicon, CA). Cells were then maintained in IMDM (20 ng/mL HGF, Chemicon, CA), $10 \mathrm{ng} / \mathrm{mL}$ bFGF, and $0.61 \mathrm{~g} / \mathrm{L}$ nicotinamide (Sigma, MO) for $7 \mathrm{~d}$. Cells were further maintained in IMDM, $20 \mathrm{mg} / \mathrm{mL}$ oncostatin $\mathrm{M}$ (OSM, Chemicon, CA), $1 \mu \mathrm{M}$ dexamethasone (Sigma, $\mathrm{MO}$ ), and $50 \mathrm{mg} / \mathrm{mL} \mathrm{ITS}^{+}$(Gibco Invitrogen, NY) for $14 \mathrm{~d}$. The hepatogenesis was assessed by real-time PCR for liver-associated genes. Both human hepatocellular carcinoma cell line (HepG2) and the primary human hepatocyte served as controls. HepG2 was maintained in DMEM/F12 (Gibco Invitrogen, NY), 10\% FBS, 100 units $/ \mathrm{mL}$ penicillin (Sigma, MO), and $100 \mu \mathrm{g} / \mathrm{mL}$ streptomycin (Sigma, MO) at $37^{\circ} \mathrm{C}$ in $5 \% \mathrm{CO}_{2}$. The primary human hepatocyte was maintained in Williams media $\mathrm{E}$ (Gibco Invitrogen, NY), 10\% FBS, 100 units $/ \mathrm{mL}$ penicillin (Sigma, MO), $100 \mu \mathrm{g} / \mathrm{mL}$ streptomycin (Sigma, MO), $4 \mu \mathrm{g} / \mathrm{mL}$ insulin and $1 \mu \mathrm{M}$ dexamethasone (Sigma, MO) at $37^{\circ} \mathrm{C}$ in $5 \% \mathrm{CO}_{2}$.

\section{Urea production assay}

MSCs, hepatocyte-like cells at passages 0-10 and HepG2 (HB-8065, ATCC, USA) were stimulated with $5 \mathrm{mM}$ $\mathrm{NH}_{4} \mathrm{Cl}$ (Sigma, MO) for $48 \mathrm{~h}$. The culture medium was collected and assayed for urea using diacetyl monoxime test[59]. The resulting diazine was measured at $540 \mathrm{~nm}$ with the SpectraMax M5 spectrofluorometer (Molecular Devices, CA).

\section{Glycogen Synthesis (Periodic Acid-Schiff, PAS) Assay}

Immortalized hepatocyte-like cells at passage 4 were cultured on a chambered slide (Lab-Tek, Nunc, Denmark) for $3 \mathrm{~d}$. The slides were fixed in $4 \%$ formaldehyde, 
permeabilized with $0.1 \%$ Triton $\mathrm{X}-100$ for $10 \mathrm{~min}$, incubated with or without diastase for $1 \mathrm{~h}$ at $37^{\circ} \mathrm{C}$, oxidized in $1 \%$ periodic acid (Sigma, MO) for $5 \mathrm{~min}$, rinsed thrice with $\mathrm{dH}_{2} \mathrm{O}$, treated with PAS reagent (Sigma, MO) for $15 \mathrm{~min}$, and rinsed with water for 5 - $10 \mathrm{~min}$. Samples were counterstained with Mayer's hematoxylin for 1 min, rinsed with water, and assessed under light microscope. The resulting gradient of oxidized glycogen would yield a gradient of color starting from pink to strong red.

\section{Analysis of cellular markers using flow cytometry}

The cultured cells were stained with fluorochrome-conjugated to primary monoclonal antibodies raised against MSC markers (CD90, CD105); hematopoietic markers (CD34, CD45) (Biosource Invitrogen, CA). For intracellular albumin accumulation, hepatocyte-like cells at passages 2-10 were incubated with FACS Perm (BD Bioscience, CA) and stained with anti-human albumin (Abcam, MA). The goat anti-mouse IgG conjugated to FITC (Santa Cruz Biotechnology, CA) was used as the secondary antibody as necessary. The labeled cells were quantitated using a FACSCalibur flow cytometer (BD Bioscience). The data were analyzed using WinMDI version 2.9.

\section{Immunofluorescence Microscopy}

Hepatocyte-like cells and the primary hepatocytes on chambered slide were washed twice with PBS, fixed with $4 \%$ paraformaldehyde for $30 \mathrm{~min}$ at room temperature followed by $100 \%$ ethanol for $10 \mathrm{~min}$. The fixed cells were washed thrice with PBS, blocked with 5\% normal serum from the same species as the secondary antibody in $1 \% \mathrm{BSA} / 0.2 \%$ Triton $\mathrm{X}-100 / \mathrm{PBS}$ for $1 \mathrm{~h}$ at room temperature. The cells were incubated with the primary antibody (anti-CYP3A4, anti-HNF4 or anti- $\alpha 1$-fetoprotein; Abcam, MA) for $1 \mathrm{~h}$ at $37^{\circ} \mathrm{C}$, washed thrice, incubated with the secondary antibody for $1 \mathrm{~h}$ at $37^{\circ} \mathrm{C}$, washed thrice, mounted with anti-fade mounting medium on coverslip, and examined under a fluorescent microscope.

The induction of major CYP450 isotypes in hepatocytelike cells using selective enzyme inducers

The modulation of expression levels of CYP450 isotypes was studied after the exposure to the classical inducers $[1,22,60,61]$. HepG2, MSC or hepatocyte like-cell from passages 3-7 at sub-confluent density were seeded on 6 well-plates for $48 \mathrm{~h}$. These cells were treated for $72 \mathrm{~h}$ with the following agents: $40 \mu \mathrm{M}$ rifampicin, $25 \mu \mathrm{M}$ dexamethasone, $50 \mu \mathrm{M}$ omeprazole, $1 \mathrm{mM}$ phenobarbital, $50 \mu \mathrm{M}$ artesunate, $88 \mu \mathrm{M}$ ethanol or $0.1 \%(\mathrm{v} / \mathrm{v})$ DMSO. The cell pellets were washed with 2-3 mL PBS, detached using $0.025 \%$ trypsin-EDTA, and neutralized with $10 \%$ FBS in IMDM. The cell pellets from passages 3-7 were pooled and stored at $-80^{\circ} \mathrm{C}$ until analysis for CYP450 gene expression.

\section{Cell isolation, extraction of total mRNA and production of cDNA from primary hepatocyte, hepatocyte-like cell, MSCs and HepG2}

The primary human hepatocytes were prepared from discarded surgical specimens using the 2-step collagenase method. The isolated cells were seeded over the collagen type IV-coated container and maintained in the above growth medium for 3 days. Total RNA isolation was performed using RNeasy Mini kit (Qiagen, Germany) according to the manufacturer's instruction. The quality and quantity of the total RNA were determined using a NanoVue Spectrophotometer (GE Healthcare, Buckinghamshire, UK). For cDNA synthesis, $2 \mu \mathrm{g}$ of total isolated RNA from primary hepatocyte, hepatocyte-like cell, HepG2 and hMSC were converted to cDNA using the ImProm-II reverse transcription system (Promega, WI). Briefly, isolated RNA was incubated with $0.5 \mu \mathrm{g}$ oligo $(\mathrm{dT})_{15}$ primer in a total volume of 5 $\mu \mathrm{L}$ at $70^{\circ} \mathrm{C}$ for $5 \mathrm{~min}$ and chilled on ice-water immediately for at least $5 \mathrm{~min}$. The reverse transcription mix $\left(15 \mu \mathrm{L}\right.$ of $5 \mathrm{X}$ reaction buffer, $25 \mathrm{mM} \mathrm{MgCl}_{2}, 2 \mathrm{mM}$ dNTP Mix, $40 \mathrm{U} / \mu \mathrm{L}$ RNasin ribonuclease inhibitor, and $200 \mathrm{U} / \mu \mathrm{L}$ Improm-II ${ }^{\mathrm{TM}} \mathrm{RT}$ ) was added to the RNA-primer mix to make a total volume of $20 \mu \mathrm{L}$. The mixture was incubated at $25^{\circ} \mathrm{C}$ for $5 \mathrm{~min}$, and $42^{\circ} \mathrm{C}$ for another 1 h. The RT reaction was terminated by heating at $70^{\circ} \mathrm{C}$ for 15 min followed by chilling on ice. The cDNA samples were either used immediately or stored at $-70^{\circ} \mathrm{C}$. The $1.2 \mathrm{~kb}$ kanamycin RNA (1 $\mu \mathrm{g})$ and non-template control served as positive and negative control system.

\section{Quantitative real-time PCR analysis for cell-specific markers}

The employed hepatocyte markers included: ALB (albumin), AFP ( $\alpha$-fetoprotein), CK18 (cytokeratin18), G6PD (glucose-6-phosphate dehydrogenase), HNF-4 $\alpha$ (hepatocyte nuclear factor $4 \alpha$ ), and TAT (tyrosine amino transferase). The employed CYP450 markers included CYP1A1, CYP1A2, CYP2C8, CYP2B6, CYP2D6, CYP2C9, CYP2C19, CYP3A4 and CYP2E1. The primers for assessing P450s included those recognized aromatic hydrocarbon receptor (AHR), pregnane $\times$ receptor (PXR), constitutive aldosterone receptor (CAR). All gene specific primers were designed using Vector NTI version 10 (Invitrogen, Table 2) and ordered from 1st BASE (Singapore). They were amplified using FastStart SYBR ${ }^{\circledR}$ Green Master (Roche diagnostic) and an ABI 7500 Sequence Detector (Applied Biosystems, CA) by following checklist information of RT-qPCR experiment (Additional file 1). Real-time PCR was performed using 
Table 2 Primer sets and conditions used in quantitative real-time PCR (qPCR)

\begin{tabular}{|c|c|c|c|c|c|c|}
\hline Gene & $\begin{array}{c}\text { Genbank } \\
\text { Accession }\end{array}$ & $\begin{array}{c}\text { Sense primer } \\
5^{\prime}--->3^{\prime}\left(\operatorname{Tm}^{\circ} \mathrm{C}\right)\end{array}$ & $\begin{array}{c}\text { Antisense primer } \\
3^{\prime}--->5^{\prime}\left(\operatorname{Tm}^{\circ} \mathrm{C}\right)\end{array}$ & $\begin{array}{c}\text { Size } \\
\text { amplicon } \\
\text { (bp) }\end{array}$ & $\begin{array}{l}\text { Annealing } \\
\text { temp. }\left({ }^{\circ} \mathrm{C}\right)\end{array}$ & Putative function \\
\hline ALB & NM_000477 & $\begin{array}{c}\text { TGAGAAAACGCCAGTAAGTGAC } \\
(60.8)\end{array}$ & $\begin{array}{c}\text { TGCGAAATCATCCATAACAGC } \\
(58.7)\end{array}$ & 265 & 60 & albumin \\
\hline AFP & NM_001134 & GCTTGGTGGTGGATGAAACA (60.4) & $\begin{array}{l}\text { TCCTCTGTTATTTGTGGCTTTTG } \\
\text { (59.2) }\end{array}$ & 157 & 60 & $\alpha$-fetoprotein \\
\hline CK18 & X12881 & GAGATCGAGGCTCTCAAGGA (62.4) & CAAGCTGGCCTTCAGATTTC (60.4) & 357 & 60 & cytokeration 18 \\
\hline G6PD & U01120 & $\begin{array}{c}\text { GCTGGAGTCCTGTCAGGCATTGC } \\
(68.1)\end{array}$ & $\begin{array}{c}\text { TAGAGCTGAGGCGGAATGGGAG } \\
(66.4)\end{array}$ & 349 & 60 & $\begin{array}{l}\text { glucose-6-phosphate } \\
\text { dehydrogenase }\end{array}$ \\
\hline HNF- $4 \alpha$ & AY680696 & GCCTACCTCAAAGCCATCAT (60.4) & GACCCTCCCAGCAGCATCTC (66.5) & 256 & 60 & $\begin{array}{l}\text { hepatocyte nuclear } \\
\text { factor } 4 \alpha\end{array}$ \\
\hline TAT & NM_000353 & TGAGCAGTCTGTCCACTGCCT (64.5) & $\begin{array}{c}\text { ATGTGAATGAGGAGGATCTGAG } \\
(60.8)\end{array}$ & 338 & 60 & tyrosine aminotransferase \\
\hline CYP2B6 & NM_000767 & $\begin{array}{c}\text { ATGGGGCACTGAAAAAGACTGA } \\
(60.8)\end{array}$ & $\begin{array}{c}\text { AGAGGCGGGGACACTGAATGAC } \\
(66.4)\end{array}$ & 283 & 60 & Cytochrome P450 2B6 \\
\hline CYP2D6 & NM_000106 & $\begin{array}{c}\text { CTAAGGGAACGACACTCATCAC } \\
(62.7)\end{array}$ & $\begin{array}{c}\text { GTCACCAGGAAAGCAAAGACAC } \\
(62.7)\end{array}$ & 289 & 60 & Cytochrome P450 2D6 \\
\hline CYP2C9 & NM_000771 & CCTCTGGGGCATTATCCATC (62.4) & $\begin{array}{l}\text { ATATTTGCACAGTGAAACATAGGA } \\
(57.7)\end{array}$ & 137 & 60 & Cytochrome P450 2C9 \\
\hline CYP2C19 & NM_000769 & TTCATGCCTTTCTCAGCAGG (60.4) & ACAGATAGTGAAATTTGGAC (54.3) & 277 & 60 & Cytochrome P450 2C19 \\
\hline CYP2C8 & NM_000770 & ACAACAAGCACCACTCTGAGATATG & GTCTGCCAATTACATGATCAATCTCT & 100 & 60 & Cytochrome P450 2C8 \\
\hline CYP3A4 & AK298451 & GCCTGGTGCTCCTCTATCTA (62.4) & $\begin{array}{c}\text { GGCTGTTGACCATCATAAAAGC } \\
(60.8)\end{array}$ & 187 & 60 & Cytochrome P450 3A4 \\
\hline CYP1A1 & BC023019 & $\begin{array}{c}\text { TCCAGAGACAACAGGTAAAACA } \\
(58.9)\end{array}$ & $\begin{array}{c}\text { AGGAAGGGCAGAGGAATGTGAT } \\
(62.7)\end{array}$ & 371 & 60 & Cytochrome P450 1A1 \\
\hline CYP1A2 & AF182274 & ACCCCAGCTGCCCTACTTG (64.5) & GCGTTGTGTCCCTTGTTGT (62.4) & 101 & 60 & Cytochrome P450 1A2 \\
\hline CYP2E1 & NM_000773 & ACCTGCCCCATGAAGCAACC (64.5) & GAAACAACTCCATGCGAGCC (62.4) & 246 & 60 & Cytochrome P450 2E1 \\
\hline PXR & AB307701 & GAAGTCGGAGGTCCCCAAA (62.3) & CTCCTGAAAAAGCCCTTGCA (60.4) & 100 & 60 & pregnane $\times$ receptor \\
\hline CAR & AB307702 & TGATCAGCTGCAAGAGGAGA (60.4) & AGGCCTAGCAACTTCGCACA (62.4) & 102 & 60 & $\begin{array}{c}\text { constitutive androstane } \\
\text { receptor }\end{array}$ \\
\hline AhR & BC070080 & ACATCACCTACGCCAGTCGC (64.5) & TCTATGCCGCTTGGAAGGAT (60.4) & 101 & 60 & $\begin{array}{l}\text { aryl hydrocarbon } \\
\text { receptor }\end{array}$ \\
\hline UGT1A1 & BC128414 & $\begin{array}{c}\text { GGAGCAAAAGGCGCCATGGC } \\
(62.5)\end{array}$ & GTCCCCTCTGCTGCAGCTGC (64.5) & 178 & 60 & $\begin{array}{c}\text { uridine diphosphate } \\
\text { glucuronyltransferase } \\
1 \mathrm{~A} 1\end{array}$ \\
\hline $\begin{array}{l}\text { LV-BMI- } \\
1\end{array}$ & NM_005180 & $\begin{array}{c}\text { GCTGAGGGCTATTGAGGCGCA } \\
(65.5)\end{array}$ & $\begin{array}{c}\text { ACCCCAAATCCCCAGGAGCTGT } \\
(65.7)\end{array}$ & 127 & 60 & lentivirus vector BMI-1 \\
\hline hBMI-1 & NM_005180 & ACCTCCCAGCCCCGCAGAAT (65.9) & AGACGCCGCTGTCAATGGGC (66.4) & 280 & 60 & human BMI-1 \\
\hline $\begin{array}{l}\text { LV- } \\
\text { hTERT }\end{array}$ & AF018167 & CAACCCGGCACTGCCCTCAG (66.9) & GGGGTTCCGCTGCCTGCAAA (68.2) & 268 & 60 & $\begin{array}{l}\text { lentivirus vector } \\
\text { telomerase reverse } \\
\text { transcriptase }\end{array}$ \\
\hline hTERT & AF018167 & $\begin{array}{c}\text { CGGAAGAGTGTCTGGAGCAAGT } \\
(59.5)\end{array}$ & $\begin{array}{c}\text { GAACAGTGCCTTCACCCTCGA } \\
(61.1)\end{array}$ & 258 & 60 & $\begin{array}{l}\text { human telomerase } \\
\text { reverse transcriptase }\end{array}$ \\
\hline
\end{tabular}

Sequence of the primers and the conditions used in quantitative real-time PCR (qPCR).

$5 \mu \mathrm{L}$ of $10 \mu \mathrm{g} / \mathrm{mL}$ cDNA diluted in a $25 \mu \mathrm{L}$ reaction mixture containing $0.4 \mu \mathrm{M}$ for each primer and $12.5 \mu \mathrm{L}$ SybrGreen with the following conditions: $95^{\circ} \mathrm{C}$ for 10 min, followed by 40 cycles of amplification at $95^{\circ} \mathrm{C}$ for $15 \mathrm{sec}, 60^{\circ} \mathrm{C}$ for $40 \mathrm{sec}$, and $72^{\circ} \mathrm{C}$ for $40 \mathrm{sec}$. The fluorescent products were measured at the last step of each cycle. To determine the specificity of amplification, melting curve analysis was applied to all final PCR products, after finishing the thermal cycling. The non- template negative control (NTC) was performed with each gene-specific primer pair. The number of cycles required for the fluorescent signal to cross the threshold (Ct's) was determined from each primer pair. The obtained Ct's were subtracted with the Ct of the respective house-keeping gene (GAPDH) of the same cells to obtain $\Delta \mathrm{Ct}$. To enable suitable comparison, the $\Delta \mathrm{Ct}$ 's of the treated cells were subtracted with $\Delta \mathrm{Ct}$ 's of the untreated cells of the same period to obtain $\Delta \Delta C t^{\prime}$ s. 
The relative fold change could be obtained from the expression of $2^{-(\Delta \Delta C t)}$.

\section{The analysis of CYP450 activity}

CYP1A1, CYP1A2, CYP2C9 and CYP3A4 enzyme activities were assayed directly in all cultured cells (immortalized hepatocyte-like cell at passage 3-7, primary human hepatocyte, HepG2 or MSC) attaching to the collagen type IV-coated 6-well plate at a density of $10^{6}$ cell/well. All cultured cells were divided into three groups. Group 1: cells were cultured in IMDM supplemented with 40 $\mu \mathrm{M}$ rifampicin to induce CYP450 isotypes $3 \mathrm{~A} 4$ and $2 \mathrm{C}$. Group 2: cells were cultured in IMDM supplemented with $50 \mu \mathrm{M}$ omeprazole for inducing CYP1A1 and CYP1A2. Group 3: cells were cultured in IMDM alone as a control. All conditions were incubated for $72 \mathrm{~h}$ with daily medium change. Metabolism was assessed based on luciferase activity using the P450-glo 1A1, 1A2, 2C9 and 3A4 assay (V8751, V8771, V8791, V9001; Promega, WI). After 3-d incubation period, cells were incubated with IMDM supplemented with $100 \mu \mathrm{M}$ Luciferin-CEE, Luciferin-H, Luciferin-ME for 3-4 h or $3 \mu \mathrm{M}$ Luciferin-IPA for 30-60 min. An aliquot $(50 \mu \mathrm{L})$ of the medium was transferred to 96-well opaque white luminometer plate (Nunc, Denmark) and luciferin detection reagent was added to each well. After sitting at room temperature for $20 \mathrm{~min}$, luminescence was measured with a SpectraMax M5 spectrofluorometer.

\section{Statistical analysis}

Each experiment was performed in triplicate. Data were expressed as mean \pm SD. Data from quantitative RTqPCR and enzyme activity were evaluated for statistical significance using the Student's unpaired $t$ test $(\mathrm{p}<$ 0.05 ). At least 3 -fold induction in mRNA with statistically significant difference was judged as relevant.

\section{Additional material}

Additional file 1: Details of quantitative RT-PCR conditions. This file contains the tabulated specific information for qRT-PCR section.

\footnotetext{
Acknowledgements

This study was funded by research grants from the Thailand Research Fund (TRF) separately awarded to S. Hongeng and A. Wongkajornsilp. K. Sangiamsuntorn is a recipient of Siriraj Graduate Thesis Scholarship. A. Wongkajornsilp is a recipient of Siriraj Chalermprakiat Fund of the Faculty of Medicine Siriraj Hospital, Mahidol University. We would like to thank Professor Amnuay Thithapandha for his help with proof reading.

\section{Author details}

${ }^{1}$ Department of Pharmacology, Faculty of Medicine Siriraj Hospital, Mahidol University, 2 Prannok Road, Bangkoknoi, Bangkok 10700, Thailand.

2Department of Surgery, Faculty of Medicine Siriraj Hospital, Mahidol University, 2 Prannok Road, Bangkoknoi, Bangkok 10700, Thailand.

${ }^{3}$ Department of Pediatrics, Faculty of Medicine Ramathibodi Hospital,
}

Mahidol University, 270 Rama VI Road, Ratchatewi, Bangkok 10400, Thailand ${ }^{4}$ Department of Pathology, Faculty of Medicine Ramathibodi Hospital, Mahidol University, 270 Rama VI Road, Ratchatewi, Bangkok 10400, Thailand. ${ }^{5}$ Department of Biotechnology, Faculty of Science, Mahidol University, 272 Rama VI Road, Ratchatewi, Bangkok 10400, Thailand.

\section{Authors' contributions}

KS performed most of the experiments, designed the protocol, performed the statistical analysis and drafted the manuscript. AW, PA, and SH designed the protocol. SL participated in the preparation of the primary hepatocytes. LN and SB prepared the vectors. AW and SH coordinated the study. SD participated in MSC culture. KK participated in qRT-PCR. All authors have read and approved the final manuscript.

Received: 13 April 2011 Accepted: 30 September 2011

Published: 30 September 2011

\section{References}

1. Zanger UM, Turpeinen M, Klein K, Schwab M: Functional pharmacogenetics/genomics of human cytochromes P450 involved in drug biotransformation. Anal Bioanal Chem 2008, 392(6):1093-1108.

2. Zamek-Gliszczynski MJ, Hoffmaster KA, Nezasa K, Tallman MN, Brouwer KL: Integration of hepatic drug transporters and phase II metabolizing enzymes: mechanisms of hepatic excretion of sulfate, glucuronide, and glutathione metabolites. Eur J Pharm Sci 2006, 27(5):447-486.

3. Uno S, Endo K, Ishida Y, Tateno C, Makishima M, Yoshizato K, Nebert DW: CYP1A1 and CYP1A2 expression: comparing 'humanized' mouse lines and wild-type mice; comparing human and mouse hepatoma-derived cell lines. Toxicol Appl Pharmacol 2009, 237(1):119-126.

4. Ripp SL, Mills JB, Fahmi OA, Trevena KA, Liras JL, Maurer TS, de Morais SM: Use of immortalized human hepatocytes to predict the magnitude of clinical drug-drug interactions caused by CYP3A4 induction. Drug Metab Dispos 2006, 34(10):1742-1748.

5. Tao XR, Li WL, Su J, Jin CX, Wang XM, Li JX, Hu JK, Xiang ZH, Lau JT, Hu YP: Clonal mesenchymal stem cells derived from human bone marrow can differentiate into hepatocyte-like cells in injured livers of SCID mice. J Cell Biochem 2009, 108(3):693-704.

6. Lange C, Bassler P, Lioznov MV, Bruns H, Kluth D, Zander AR, Fiegel HC: Hepatocytic gene expression in cultured rat mesenchymal stem cells. Transplant Proc 2005, 37(1):276-279.

7. Pan RL, Chen Y, Xiang LX, Shao JZ, Dong XJ, Zhang GR: Fetal liverconditioned medium induces hepatic specification from mouse bone marrow mesenchymal stromal cells: a novel strategy for hepatic transdifferentiation. Cytotherapy 2008, 10(7):668-675.

8. Shimomura T, Yoshida Y, Sakabe T, Ishii K, Gonda K, Murai R, Takubo K, Tsuchiya H, Hoshikawa Y, Kurimasa A, et al: Hepatic differentiation of human bone marrow-derived UE7T-13 cells: Effects of cytokines and CCN family gene expression. Hepatol Res 2007, 37(12):1068-1079.

9. Banas A, Teratani T, Yamamoto Y, Tokuhara M, Takeshita F, Quinn G, Okochi H, Ochiya T: Adipose tissue-derived mesenchymal stem cells as a source of human hepatocytes. Hepatology 2007, 46(1):219-228.

10. Zemel R, Bachmetov L, Ad-El D, Abraham A, Tur-Kaspa R: Expression of liver-specific markers in naive adipose-derived mesenchymal stem cells. Liver Int 2009, 29(9):1326-1337.

11. Yamamoto Y, Banas A, Murata S, Ishikawa M, Lim CR, Teratani T, Hatada I, Matsubara K, Kato T, Ochiya T: A comparative analysis of the transcriptome and signal pathways in hepatic differentiation of human adipose mesenchymal stem cells. FEBS J 2008, 275(6):1260-1273.

12. Saulnier N, Lattanzi W, Puglisi MA, Pani G, Barba M, Piscaglia AC, Giachelia M, Alfieri S, Neri G, Gasbarrini G, et al: Mesenchymal stromal cells multipotency and plasticity: induction toward the hepatic lineage. Eur Rev Med Pharmacol Sci 2009, 13(Suppl 1):71-78.

13. Campard D, Lysy PA, Najimi M, Sokal EM: Native umbilical cord matrix stem cells express hepatic markers and differentiate into hepatocyte-like cells. Gastroenterology 2008, 134(3):833-848.

14. Zhao Q, Ren H, Li X, Chen Z, Zhang X, Gong W, Liu Y, Pang T, Han ZC: Differentiation of human umbilical cord mesenchymal stromal cells into low immunogenic hepatocyte-like cells. Cytotherapy 2009, 11(4):414-426.

15. Anzalone R, lacono ML, Corrao S, Magno F, Loria T, Cappello F, Zummo G, Farina F, La Rocca G: New emerging potentials for human Wharton's jelly 
mesenchymal stem cells: immunological features and hepatocyte-like differentiative capacity. Stem Cells Dev 2010, 19(4):423-438.

16. Stock $P$, Bruckner $S$, Ebensing $S$, Hempel M, Dollinger MM, Christ B: The generation of hepatocytes from mesenchymal stem cells and engraftment into murine liver. Nat Protoc 2010, 5(4):617-627.

17. Cho CH, Parashurama N, Park EY, Suganuma K, Nahmias Y, Park J, Tilles AW, Berthiaume F, Yarmush ML: Homogeneous differentiation of hepatocytelike cells from embryonic stem cells: applications for the treatment of liver failure. FASEB J 2008, 22(3):898-909.

18. Piryaei A, Valojerdi MR, Shahsavani M, Baharvand H: Differentiation of Bone Marrow-derived Mesenchymal Stem Cells into Hepatocyte-like Cells on Nanofibers and Their Transplantation into a Carbon TetrachlorideInduced Liver Fibrosis Model. Stem Cell Rev 2011, 7(1):103-18.

19. Aurich I, Mueller LP, Aurich $H$, Luetzkendorf J, Tisljar K, Dollinger MM, Schormann W, Walldorf J, Hengstler JG, Fleig WE, et al: Functional integration of hepatocytes derived from human mesenchymal stem cells into mouse livers. Gut 2007, 56(3):405-415.

20. Yan Y, Xu W, Qian H, Si Y, Zhu W, Cao H, Zhou H, Mao F: Mesenchymal stem cells from human umbilical cords ameliorate mouse hepatic injury in vivo. Liver Int 2009, 29(3):356-365.

21. Ren H, Zhao Q, Cheng T, Lu S, Chen Z, Meng L, Zhu X, Yang S, Xing W, Xiao $Y$, et al: No contribution of umbilical cord mesenchymal stromal cells to capillarization and venularization of hepatic sinusoids accompanied by hepatic differentiation in carbon tetrachloride-induced mouse liver fibrosis. Cytotherapy 2010, 12(3):371-383.

22. Ek M, Soderdahl T, Kuppers-Munther B, Edsbagge J, Andersson TB, Bjorquist P, Cotgreave I, Jernstrom B, Ingelman-Sundberg M, Johansson I: Expression of drug metabolizing enzymes in hepatocyte-like cells derived from human embryonic stem cells. Biochem Pharmacol 2007, 74(3):496-503.

23. Shiojiri N, Sugiyama Y: Immunolocalization of extracellular matrix components and integrins during mouse liver development. Hepatology 2004, 40(2):346-355.

24. Le Lay J, Kaestner KH: The Fox genes in the liver: from organogenesis to functional integration. Physiol Rev 2010, 90(1):1-22.

25. Unger C, Gao S, Cohen M, Jaconi M, Bergstrom R, Holm F, Galan A, Sanchez E, Irion O, Dubuisson JB, et al: Immortalized human skin fibroblast feeder cells support growth and maintenance of both human embryonic and induced pluripotent stem cells. Hum Reprod 2009, 24(10):2567-2581.

26. Aninat C, Piton A, Glaise D, Le Charpentier T, Langouet S, Morel F, GuguenGuillouzo C, Guillouzo A: Expression of cytochromes P450, conjugating enzymes and nuclear receptors in human hepatoma HepaRG cells. Drug Metab Dispos 2006, 34(1):75-83.

27. Maronpot RR, Yoshizawa K, Nyska A, Harada T, Flake G, Mueller G, Singh B, Ward JM, Botts S: Hepatic Enzyme Induction: Histopathology. Toxicol Pathol 2010, 38(5):776-95.

28. Sinz M, Wallace G, Sahi J: Current industrial practices in assessing CYP450 enzyme induction: preclinical and clinical. AAPS J 2008, 10(2):391-400.

29. Ishii K, Yoshida Y, Akechi Y, Sakabe T, Nishio R, Ikeda R, Terabayashi K, Matsumi Y, Gonda K, Okamoto H, et al: Hepatic differentiation of human bone marrow-derived mesenchymal stem cells by tetracycline-regulated hepatocyte nuclear factor 3beta. Hepatology 2008, 48(2):597-606.

30. Zheng YB, Gao ZL, Xie C, Zhu HP, Peng L, Chen JH, Chong YT: Characterization and hepatogenic differentiation of mesenchymal stem cells from human amniotic fluid and human bone marrow: a comparative study. Cell Biol Int 2008, 32(11):1439-1448.

31. Burk O, Koch I, Raucy J, Hustert E, Eichelbaum M, Brockmoller J, Zanger UM, Wojnowski L: The induction of cytochrome P450 3A5 (CYP3A5) in the human liver and intestine is mediated by the xenobiotic sensors pregnane $\times$ receptor (PXR) and constitutively activated receptor (CAR). J Biol Chem 2004, 279(37):38379-38385.

32. Chen ML, Lee KD, Huang HC, Tsai YL, Wu YC, Kuo TM, Hu CP, Chang C: HNF-4alpha determines hepatic differentiation of human mesenchymal stem cells from bone marrow. World I Gastroenterol 2010, 16(40):5092-5103.

33. Banas A, Yamamoto $Y$, Teratani $T$, Ochiya T: Stem cell plasticity: learning from hepatogenic differentiation strategies. Dev Dyn 2007, 236(12):3228-3241.
34. Zhang YN, Lie PC, Wei X: Differentiation of mesenchymal stromal cells derived from umbilical cord Wharton's jelly into hepatocyte-like cells. Cytotherapy 2009, 11(5):548-558.

35. Aurich H, Sgodda M, Kaltwasser P, Vetter M, Weise A, Liehr T, Brulport M, Hengstler JG, Dollinger MM, Fleig WE, et al: Hepatocyte differentiation of mesenchymal stem cells from human adipose tissue in vitro promotes hepatic integration in vivo. Gut 2009, 58(4):570-581.

36. Hay DC, Zhao D, Ross A, Mandalam R, Lebkowski J, Cui W: Direct differentiation of human embryonic stem cells to hepatocyte-like cells exhibiting functional activities. Cloning Stem Cells 2007, 9(1):51-62.

37. Ksiazek K: A comprehensive review on mesenchymal stem cell growth and senescence. Rejuvenation Res 2009, 12(2):105-116.

38. Gjerdrum C, Tiron C, Hoiby T, Stefansson I, Haugen H, Sandal T, Collett K, Li S, McCormack E, Gjertsen BT, et al: Axl is an essential epithelial-tomesenchymal transition-induced regulator of breast cancer metastasis and patient survival. Proc Natl Acad Sci USA 2010, 107(3):1124-1129.

39. Wagner W, Horn P, Castoldi M, Diehlmann A, Bork S, Saffrich R, Benes V, Blake J, Pfister S, Eckstein V, et al: Replicative senescence of mesenchymal stem cells: a continuous and organized process. PLoS One 2008, 3(5): e2213.

40. Boker W, Yin Z, Drosse I, Haasters F, Rossmann O, Wierer M, Popov C, Locher M, Mutschler W, Docheva D, et al: Introducing a single-cell-derived human mesenchymal stem cell line expressing hTERT after lentiviral gene transfer. J Cell Mol Med 2008, 12(4):1347-1359.

41. Wolbank S, Stadler G, Peterbauer A, Gillich A, Karbiener M, Streubel B, Wieser M, Katinger H, van Griensven M, Redl H, et al: Telomerase immortalized human amnion- and adipose-derived mesenchymal stem cells: maintenance of differentiation and immunomodulatory characteristics. Tissue Eng Part A 2009, 15(7):1843-1854

42. Abdallah BM, Haack-Sorensen M, Burns JS, Elsnab B, Jakob F, Hokland P, Kassem M: Maintenance of differentiation potential of human bone marrow mesenchymal stem cells immortalized by human telomerase reverse transcriptase gene despite [corrected] extensive proliferation. Biochem Biophys Res Commun 2005, 326(3):527-538.

43. Masutomi K, Yu EY, Khurts S, Ben-Porath I, Currier JL, Metz GB, Brooks MW, Kaneko S, Murakami S, DeCaprio JA, et al: Telomerase maintains telomere structure in normal human cells. Cell 2003, 114(2):241-253.

44. Zhao YM, Li JY, Lan JP, Lai XY, Luo Y, Sun J, Yu J, Zhu YY, Zeng FF, Zhou Q et al: Cell cycle dependent telomere regulation by telomerase in human bone marrow mesenchymal stem cells. Biochem Biophys Res Commun 2008, 369(4):1114-1119.

45. Jagani Z, Wiederschain D, Loo A, He D, Mosher R, Fordjour P, Monahan J, Morrissey M, Yao YM, Lengauer C, et al: The Polycomb group protein Bmi1 is essential for the growth of multiple myeloma cells. Cancer Res 2010, 70(13):5528-5538.

46. Kim RH, Lieberman MB, Lee R, Shin KH, Mehrazarin S, Oh JE, Park NH, Kang MK: Bmi-1 extends the life span of normal human oral keratinocytes by inhibiting the TGF-beta signaling. Exp Cell Res 2010, 316(16):2600-2608

47. Sanchez A, Fabregat I: Growth factor- and cytokine-driven pathways governing liver stemness and differentiation. World J Gastroenterol 2010, 16(41):5148-5161.

48. Harrington $L$ : Does the reservoir for self-renewal stem from the ends? Oncogene 2004, 23(43):7283-7289.

49. Kolquist KA, Ellisen LW, Counter CM, Meyerson M, Tan LK, Weinberg RA, Haber DA, Gerald WL: Expression of TERT in early premalignant lesions and a subset of cells in normal tissues. Nat Genet 1998, 19(2):182-186.

50. Schieker M, Gulkan H, Austrup B, Neth P, Mutschler W: Telomerase activity and telomere length of human mesenchymal stem cells. Changes during osteogenic differentiation. Orthopade 2004, 33(12):1373-1377.

51. Simonsen JL, Rosada C, Serakinci N, Justesen J, Stenderup K, Rattan SI, Jensen TG, Kassem M: Telomerase expression extends the proliferative life-span and maintains the osteogenic potential of human bone marrow stromal cells. Nat Biotechnol 2002, 20(6):592-596.

52. Jun ES, Lee $T H$, Cho HH, Suh SY, Jung JS: Expression of telomerase extends longevity and enhances differentiation in human adipose tissue-derived stromal cells. Cell Physiol Biochem 2004, 14(4-6):261-268.

53. Salmon P, Oberholzer J, Occhiodoro T, Morel P, Lou J, Trono D: Reversible immortalization of human primary cells by lentivector-mediated transfer of specific genes. Mol Ther 2000, 2(4):404-414. 
54. Talens-Visconti R, Bonora A, Jover R, Mirabet V, Carbonell F, Castell JV, Gomez-Lechon MJ: Hepatogenic differentiation of human mesenchymal stem cells from adipose tissue in comparison with bone marrow mesenchymal stem cells. World J Gastroenterol 2006, 12(36):5834-5845.

55. Ong SY, Dai H, Leong KW: Hepatic differentiation potential of commercially available human mesenchymal stem cells. Tissue Eng 2006, 12(12):3477-3485.

56. Moon YJ, Lee MW, Yoon HH, Yang MS, Jang IK, Lee JE, Kim HE, Eom YW, Park JS, Kim HC, et al: Hepatic differentiation of cord blood-derived multipotent progenitor cells (MPCs) in vitro. Cell Biol Int 2008, 32(10):1293-1301.

57. Si-Tayeb K, Noto FK, Nagaoka M, Li J, Battle MA, Duris C, North PE, Dalton S, Duncan SA: Highly efficient generation of human hepatocyte-like cells from induced pluripotent stem cells. Hepatology 2010, 51(1):297-305.

58. Sekiya I, Larson BL, Smith JR, Pochampally R, Cui JG, Prockop DJ: Expansion of human adult stem cells from bone marrow stroma: conditions that maximize the yields of early progenitors and evaluate their quality. Stem Cells 2002, 20(6):530-541.

59. Wybenga DR, Di Giorgio J, Pileggi VJ: Manual and automated methods for urea nitrogen measurement in whole serum. Clin Chem 1971, 17(9):891-895.

60. Youdim KA, Tyman CA, Jones BC, Hyland R: Induction of cytochrome P450: assessment in an immortalized human hepatocyte cell line (Fa2N4) using a novel higher throughput cocktail assay. Drug Metab Dispos 2007, 35(2):275-282.

61. Bort R, Signore M, Tremblay K, Martinez Barbera JP, Zaret KS: Hex homeobox gene controls the transition of the endoderm to a pseudostratified, cell emergent epithelium for liver bud development. Dev Biol 2006, 290(1):44-56.

doi:10.1186/1472-6750-11-89

Cite this article as: Sa-ngiamsuntorn et al: Upregulation of CYP 450s expression of immortalized hepatocyte-like cells derived from mesenchymal stem cells by enzyme inducers. BMC Biotechnology 2011 11:89.

\section{Submit your next manuscript to BioMed Central} and take full advantage of:

- Convenient online submission

- Thorough peer review

- No space constraints or color figure charges

- Immediate publication on acceptance

- Inclusion in PubMed, CAS, Scopus and Google Scholar

- Research which is freely available for redistribution 